\section{Control of Solanum americanum with Paraquat Impaired by Some Fungicides/Bactericides}

\author{
Thomas A. Bewick, William M. Stall, Stephen R. Kostewicz, and \\ Kenneth Smith \\ Vegetable Crops Department, University of Florida, Gainesville, \\ FL 32611
}

Additional index words. American black nightshade, pesticide interaction, weed control, herbicide tolerance

\begin{abstract}
Cupric hydroxide, copper ammonium carbonate, basic copper sulfate, mancozeb, and a combination of cupric hydroxide and mancozeb were applied to American black nightshade (Solanum americanum Mill) before treatment with paraquat at 0.6 kg a.i./ha. Paraquat efficacy was reduced by all fungicides/bactericides, except a flowable formulation of basic copper sulfate, when compared to the herbicide only control. Compared to a surfactant only control, efficacy 1 week after paraquat application ranged from $86 \%$ with paraquat only to $42 \%$ with a combination of mancozeb and cupric hydroxide. Mancozeb and mancozeb in combination with cupric hydroxide resulted in greater shoot dry weight than the paraquat only control when measured 2 weeks after herbicide application. Chemical names used: 1,1'-dimethyl-4-4'-bipyridinium ion (paraquat); Mn, $\mathrm{Zn}$ ethylene bis diethyldithiocarbamate (mancozeb).
\end{abstract}

American black nightshade is the most troublesome weed occurring in Florida tomato production fields (Gilreath et al., 1989). If not controlled, nightshade can reduce yield (Weaver et al., 1987), act as an alternate host for sweetpotato whitefly (Bemisia tabaci) (Gilreath et al., 1989), and impair harvest. Paraquat, a nonselective herbicide, is used extensively as a shielded postemergence application to control nightshade and other weeds growing between rows of mulched to-

Received for publication 16 Oct. 1989. Florida Agricultural Experiment Station Journal Series no. $\mathrm{R}-00190$. The cost of publishing this paper was defrayed in part by the payment of page charges. Under postal regulations, this paper therefore must be hereby marked advertisement solely to indicate this fact. mate. There are no registered selective herbicides for control of American black nightshade in tomato. Currently, paraquat is the only reasonable management tool available for control of emerged broadleaf weeds between mulched beds. Recent reports from tomato production areas (Stall et al., 1987) have indicated a reduction in paraquat efficacy against American black nightshade. $\mathrm{Pa}$ raquat is also used in row middles of other crops, but reduction in paraquat efficacy in these crops has not been widely reported.

Disease control is also essential for profitable tomato production. Commonly, copper-containing fungicides/bactericides $(\mathrm{F} / \mathrm{B})$ or mancozeb are used to control several important pathogens of tomato (Jones and Jones, 1989); thus, American black nightshade is often inadvertently treated. Previous re- search indicated that copper-containing F/B on the leaves of American black nightshade reduced paraquat efficacy against this weed (Stall et al., 1987, 1988). Antagonism of other F/B to herbicides has been reported (Hatzios and Penner, 1985). Also, paraquatresistant biotypes of American black nightshade have been described recently (Bewick et al., 1989). The level of paraquat resistance is increased in the presence of coppercontaining $\mathrm{F} / \mathrm{B}$ in the paraquat-resistant biotype, but not in the paraquat-sensitive biotype (Bewick et al., 1989).

The purpose of this study was to determine if there were sources of copper-containing $\mathrm{F} / \mathrm{B}$, or other metallo-F/B, that could be used to protect tomato against common diseases at manufacturer-recommended dosages without reducing the efficacy of paraquat against American black nightshade.

A paraquat-resistant biotype of American black nightshade was collected from the $\mathrm{Na}$ ples, Fla., area. This biotype has been shown to be 14 times more resistant to paraquat than a susceptible biotype (unpublished data). Seeds of the resistant biotype were planted in flats in a greenhouse in a commercially prepared soil mix [30\% sphagnum peat, $50 \%$ vermiculite, $18 \%$ perlite, $2 \%$ granite sand, (Metro-mix 200; Gracewood Horticultural Products, Cambridge, Mass.)]. Seedlings were transplanted at the second true-leaf stage to $110-\mathrm{mm}$-diameter (1 liter) plastic pots that contained the same soil medium as the planting trays. Plants were grown in a greenhouse set at a minimum of $13 \mathrm{C}$ and a maximum of 24C. An automatic watering system, which ran four times each day for a total of $12 \mathrm{~min}$, was used. Drip tubes were used in each pot to avoid washing the F/El from the foliage.

$\mathrm{F} / \mathrm{B}$ treatments were initiated at the four true-leaf stage. All F/B were applied three times at 48-hr intervals at manufacturer-recommended dosages (Table 1) with a $\mathrm{CO}_{2-}$ pressurized sprayer using a diluent at $22 \mathrm{li}$ ters $\cdot \mathrm{ha}^{-1}$. One day after the last F/B application, paraquat was applied at $0.6 \mathrm{~kg}$ a.i./ ha using the same delivery system as for the 
Table 1. Effect of preherbicide application of fungicides/bactericides (F/B) on efficacy of paraquat against American black nightshade. ${ }^{2}$

\begin{tabular}{lccc}
\hline \hline & $\begin{array}{c}\text { Dosage } \\
\text { Treatmenty }\end{array}$ & & $\begin{array}{c}\text { Shoot } \\
\text { dry wt } \\
\text { (g) }\end{array}$ \\
\hline Paraquat + surfactant & 0.6 & 0.7 & 0.40 \\
Basic copper sulfate F & Leaf no. & 0.34 \\
Basic copper sulfate WPw & 1.8 & 1.1 & 0.51 \\
Cupric hydroxide & 4.8 & 1.9 & 0.57 \\
Copper ammonium carbonate & 2.8 & 2.0 & 0.64 \\
Mancozeb & 0.7 & 2.0 & 0.71 \\
Mancozeb + cupric hydroxide & 3.6 & 2.4 & 0.87 \\
Surfactant only & $3.6+2.8$ & 3.8 & 1.88 \\
LSD & & 6.7 & 0.27 \\
\hline
\end{tabular}

${ }^{2}$ Data are the averages of two experiments. Leaf number counted 1 week after and dry weight determined 2 weeks after paraquat application.

'All F/B applied three times. Paraquat applied to all treatments at $0.6 \mathrm{~kg}$ a.i./ha with $\mathrm{X}-77$ at $0.25 \%$ (v/v) as a surfactant, except in surfactant only control. Paraquat applied 1 day after the last F/B treatment. 'Flowable formulation.

"Wettable powder formulation.

F/B. X-77 (a nonionic spreader activator, principle functioning agents: glycols, alkylarypoloxy ethylene, free fatty acids, isopropanol; Chevron Chemical Co., Redwood, Calif.) at $0.25 \%(\mathrm{v} / \mathrm{v})$ was used as a surfactant. Two controls were used: paraquat + surfactant and surfactant only. Plants were in the six true-leaf stage at the time of paraquat application.

One week after paraquat application, efficacy was determined by counting the number of leaves remaining on the plants. Two weeks after paraquat application, regrowth was determined by harvesting the shoots, drying them in an oven at $70 \mathrm{C}$ for 5 days, and recording dry weight. Dead shoots were not included in the analysis.

The experiment was arranged as a randomized complete block with four replications and five plants per treatment per replication. The experiment was repeated. Analysis of variance was used to determine that there was no interaction between experiments, and data were pooled across experiments. Pooled data were used to compute treatment means, and means were compared using the least significant difference method at $P=0.05$.

The number of leaves remaining on American black nightshade plants was reduced from about seven for the surfactant only control to $\leq 1$ for the paraquat + surfactant control (Table 1). Three applications of a flowable formulation of basic copper sulfate before paraquat application did not reduce herbicide efficacy. Three applications of cupric hydroxide, copper ammonium carbonate, mancozeb, or a wettable powder formulation of basic copper sulfate before paraquat application reduced herbicide activity (two leaves remaining per plant). Herbicide activity was further reduced when a combination of cupric hydroxide and mancozeb was applied to the plants before paraquat application (four leaves remaining per plant). The flowable formulation of basic copper sulfate, used to protect crops from certain plant pathogens, was the only treatment that did not protect American black nightshade from the herbicidal effects of paraquat.

Plant regrowth, expressed as shoot dry weight, did not vary as much among $\mathrm{F} / \mathrm{B}$ as leaf number (Table 1). Plants treated with surfactant weighed more than plants treated with $\mathrm{F} / \mathrm{B}$ followed by paraquat application. The weight of plants treated with cupric hydroxide, copper ammonium carbonate, or either formulation of basic copper sulfate before paraquat application was the same as the weight of plants treated only with paraquat
+ surfactant. Because the biotype of American black nightshade used in this experiment was resistant to paraquat, there was considerable regrowth when the plants were treated with paraquat + surfactant. This result masked the effects of the F/B treatments with regard to plant regrowth. Regrowth of plants treated with mancozeb, or a combination of mancozeb and cupric hydroxide, was greater than of plants treated with paraquat + surfactant.

The number of leaves remaining 1 week after paraquat application indicates that the flowable formulation of basic copper sulfate, used for disease control in crops, will not reduce the efficacy of paraquat against a biotype of American black nightshade resistant to paraquat. This maybe important to tomato producers, since paraquat is more effective against various grass weed species than other registered chemicals.

\section{Literature Cited}

Bewick, T.A., W.M. Stall, and S.R. Kostewicz. 1989. Resistance of American black nightshade to paraquat. Proc. Southern Weed Sci. Soc. 42:151. (Abstr.)

Gilreath, J.P., P.R. Gilreath, W.M. Stall, and D.J. Schuster. 1989. Management of weeds and crop residues. Florida Tomato Inst. Proc. 28th Annu. Meeting, Naples, Fla. p. 30-33.

Hatzios, K.K. and D. Penner. 1985. Interactions of herbicides with other agrochemicals in higher plants. Rev. Weed Sci. 1:1-63.

Jones, J.P. and J.B. Jones. 1989. Target spot, early blight, bacterial spot, and bacterial speck: Identification and control. Florida Tomato Inst. Proc. 28th Annu. Meeting, Naples, Fla. p. 4244.

Stall, W.M., S.R. Kostewicz, and T.A. Bewick 1988. Effect of copper on paraquat activity against common nightshade. HortScience 23:141. (Abstr.)

Stall, W.M., S.R. Kostewicz, and R.L. Brown. 1987. Reduction in control of common nightshade (Solanum americanum) by paraquat due to copper fungicides. Florida State Hort. Soc. 1987. Proc. 100th Annu. Meeting, Orlando, Fla. p. 222-224.

Weaver, S.E., N. Smits, and C.S. Tan. 1987. Estimating yield loss of tomatoes (Lycopersicon esculentum) caused by nightshade (Solanum spp.). Weed Sci. 35:163-168. 